\title{
SUSCEPTIBILIDADE DE BACTÉRIAS PREVALENTES EM INFECÇÕES NOSOCOMIAIS AS SUBSTÂNCIAS ISOLADAS OBTIDAS DA RAIZ DE Cochlospermum regium
}

Rafaella S. Carvalho*, Juliana M. C. Palumbo, João M. Siqueira, José C. Magalhães, Jaqueline M. S. Ferreira

Universidade Federal de João Del Rei (UFSJ), Divinópolis/MG

*e-mail: rafaellascarvalho@yahoo.com.br

\section{Resumo}

A espécie Cochlospermum regium, conhecida popularmente como algodãozinho, é aplicada tradicionalmente na medicina popular no tratamento e controle de várias doenças infecciosas. Diante dos poucos estudos disponíveis sobre a atividade antibacteriana da $C$. regium e a ampla resistência que as bactérias vem apresentando, o objetivo deste trabalho foi avaliar a atividade in vitro bacteriostática e bactericida das substâncias isoladas da raíz de C. regium frente às bactérias Gram negativas Escherichia coli (ATCC 25.723), Acinetobacter baumannii (ATCC 19.606) e Pseudomonas aeruginosa (ATCC 25619) e Gram positivas Staphylococcus aureus (ATCC 29.213) e Staphylococcus epidermidis (ATCC 12.228). Os valores de concentração inibitória mínima (CIM) e a concentração bactericida mínima (CBM) correspondem à menor concentração da substância capaz de inibir o crescimento bacteriano. Para atingir este objetivo, o CIM do tanino e ácido gálico foram determinados através da técnica de microdiluição em caldo e, posteriormente, foi realizado o teste bactericida para determinar o CBM. As substâncias ácido gálico e tanino isolados do $C$. regium foram diluídos em concentrações que variaram de 1000 a $31,25 \mu \mathrm{g} / \mathrm{mL}$ em dimetilsufóxido $20 \%$. O ácido gálico apresentou a melhor atividade frente a $S$. aureus e E. coli com valores de CIM de 500 e $250 \mu \mathrm{g} / \mathrm{mL}$, respectivamente. O tanino apresentou CIM com valores de $1000 \mu \mathrm{g} / \mathrm{mL}$ frente a E.coli, $125 \mu \mathrm{g} / \mathrm{mL}$ em relação a $P$. aeruginosa, $62,5 \mu \mathrm{g} / \mathrm{mL}$ frente a $S$. epidermidis, seguida da A. baumannii com CIM de $31,25 \mu \mathrm{g} / \mathrm{mL}$. O CBM obtido para o ácido gálico foi de $500 \mu \mathrm{g} / \mathrm{mL}$ contra E. coli enquanto o 
tanino mostrou CBM de $1000 \mu \mathrm{g} / \mathrm{mL}$ frente a A. baumannii, S. aureus e $S$. epidermidis. Os resultados obtidos mostraram que as substâncias identificadas de C. regium possuem potencial antibacteriano, oferecendo subsídios para a pesquisa e descoberta de agentes antimicrobianos derivados desse vegetal.

Palavras-chave: Cochlospermum regium, tanino e ácido gálico.

Apoio financeiro: CNPq, FAPEMIG, UFSJ. 